\title{
3rd ICTs and Society Meeting; Paper Session - Theorizing the Internet; Paper 4: A Methodological Reflection on Converging Technologies and Their Relevance to Informa- tion Ethics
}

\author{
Pak-Hang Wong \\ Department of Philosophy, University of Twente, The Netherlands, p.h.wong@utwente.nl
}

\begin{abstract}
In light of converging technologies, there is a clear sense that ethicists of various technological domains are coming together. Or, that they should come together. Yet, despite increasing cooperation and boundary-crossing in various fields of the ethics of technology, these efforts remain mostly at topical level. Relatively little attention has been given to issues on methodologies. The current paper aims to contribute to the current research by raising the methodological issues. In this paper, my objective is to argue that ethics of Information Technology (or Information Ethics (IE)) can benefit from the insights in other fields of the ethics of technology. Drawing the insights from other fields of the ethics of technology, I shall propose a systematic account of an Empirical Information Ethics (EIE)
\end{abstract}

Keywords: Converging Technologies, Information Technology, Information Ethics, Ethics of Technology, Bioethics, Empirical Ethics, Empirical Information Ethics, Well-Being

Recent technological innovations are progressively marching towards a direction of convergence, that is - there is a hybridisation of various technological domains, which involves at least, but not only, Nanotechnology, Biotechnology, Information Technology and Cognitive Science (or "NBIC technologies"). (e.g., Roco \& Bainbridge, 2002) As such, converging technologies have blurred the onceclear boundaries of various technological domains. The blurring of boundaries, in turns, has presented novel challenges to the ethics of technology, where its focus is often domain-specific until recently. At the same time, however, converging technologies have also created new opportunities for ethicists of different technological domains to cooperate, and, perhaps, to develop the ethical theory of (converging) technology.

Among various technological domains in converging technologies, Information Technology offers the infrastructure for information exchange. This, together with the informational nature of our ontology (see, e.g. Floridi 2007, 2008a, 2008b \& 2010), only assures that the role and the importance of Information Technology will continue to rise in the future. The latest research in Information Ethics has already provided hints of that trend. For example, Luciano Floridi's recent research on bio-information and e-Health (see, www.philosophyofinformation.net) are excellent illustrations of that trend. Other topics, including nano-computing and bio-computing, human enhancement with Information Technology, etc., are also on the rise, too. (e.g. Stahl \& Rogerson, 2009; see also, SPT 2009: Converging Technologies, Changing Societies).

In light of converging technologies, there is, therefore, a clear sense that ethicists of various technological domains are coming together. Or, that they should come together. Yet, despite increasing cooperation and 
boundary-crossing in various fields of the ethics of technology, these efforts remain mostly at topical level, i.e. the hybridisation of technological domains is seen to have generated new moral and political problems in terms of types and subjects of investigation. Relatively little attention has been given to issues at the methodological level, i.e. the possibility of a methodological convergence in light of converging technologies. The current research, therefore, leaves open an interesting question concerning the possibility of convergence not only at the level of topics, but also on their methodologies.

The current paper aims to contribute to the current research by raising the methodological issues. Particularly, my objective is to argue that ethics of Information Technology (or Information Ethics (IE)) can benefit from the insights in other fields of the ethics of technology. And, my focus will be on the recent developments in Bioethics. My choice of Bioethics is not arbitrary because Bioethics, as a discipline of applied ethical inquiry, has earned a relatively clear status of independence (see, e.g. Jonsen, 1998) and it has also undergone a thorough internal methodological debate (see, e.g. Beauchamp \& Childress, 2001, Borry et al., 2006). The history of Bioethics and its methodological selfreflection, I think, have provided appropriate anchor to reflection in other fields of applied ethical inquiry.

Here, my particular emphasis is on the recent development of empirical (bio)ethics in Bioethics. (see, Borry et al., 2004, 2006) Empirical ethics is characterised by its attempts to integrate empirical data into normative, ethical analyses. There is, of course, a clear sense in which applied ethical inquiries, including (IE), have always relied on some empirical data in theorising. Thus, it will be helpful first to distinguish different ways in which empirical data are being used. Here, Molewijk et al. (2004a) have usefully described various ways in which empirical data can be incorporated into ethical inquires. I shall summarise their categories, i.e.

(i) prescriptive applied ethicists, (ii) theorists,

(iii) critical applied ethicists,

(iv) particularists, and

(v) integrated empirical ethics.

Then, I will describe how empirical data are currently being used in (IE). And, I shall illustrate, very few current studies in (IE) belong to the category $(v)$.

After identifying the current use of empirical data in (IE), I shall briefly return to the methodological debate in Bioethics, and explain why a substantial place for empirical data is found wanting in Bioethics. (see, e.g. Borry, 2004, 2006; van der Scheer \& Widdershoven, 2004a, 2004b; Molewijk, 2004b; Leget, Borry \& de Vries, 2009; Widdershoven et al., 2009) Then, I will juxtapose the reasons for integrating empirical data in Bioethics to (IE). I shall argue, among other advantages empirical ethics has over its competitors, that it allows ethicists to take seriously the stakeholders' experience in ethical inquiries, which (IE) seems to have excluded thus far. Taking seriously the stakeholders' experience, I will point out, has special implication to questions pertaining to the relation between Information Technology and individuals' well-being. For a person's past experience and future expectation are intimately linked to his/her well-being.

Finally, I shall conclude by offering a more systematic account of an Empirical Information Ethics (EIE). A systematic account of an (EIE), I shall argue, requires us to go beyond the traditional ethical theories, e.g. deontology, utilitarianism or virtue-based ethics, because mechanisms to include the stakeholders' experience into (IE) are needed. Here, I think that research in Hermeneutics (see, Widdershoven et al., 2009) and/or Discourse Studies (see, e.g. Fairclough, 2003, 2010; Wodak \& Krzyzanowski, 2008; Wodak $\&$ Meyer, 2009) may help us to forge the connection between (IE) and empirical data. Hence, I will illustrate how Hermeneutics and Discourse Studies can play this role, and propose some directions for future research. 


\section{References}

Beauchamp, T.L., \& Childress, J.F. (Eds.) (2001). Principles of biomedical ethics (5th ed.). New York, NY: Oxford University Press.

Borry, P., Schootsmann P., \& Dierckx, K. (2006). The Birth of the Empirical Turn in Bioethics. Bioethics 19 (1), $49-71$.

Borry, P., Schootsmann P., \& Dierckx, K. (2004). Empirical ethics. A challenge to bioethics. Medicine, Health Care and Philosophy, 7 (1), 1-3.

Fairclough, N. (2003). Analysing Discourse: Textual Analysis for Social Research. London: Routledge.

Fairclough, N. (2010). Critical Discourse Analysis:The Critical Study of Language (2nd ed.). London: Longman.

Floridi, L. (2010). Information: A Very Short Introduction. New York: Oxford University Press.

Floridi, L. (2008a). Foundations of Information Ethics. In K. E. Himma \& Herman T. Tavani (Eds.), Handbook of Information and Computer Ethics (pp. 3-23). Hoboken, NJ:. John Wiley \& Sons.

Floridi, L. (2008b). Information Ethics, its Nature and Scope. In J. van den Hoven \& J. Weckert (Eds.), Information Technology and Moral Philosophy (pp. 40-65). Cambridge, NY: Cambridge University Press.

Floridi, L. (2007). A Look into the Future Impact of ICT on Our Lives, The Information Society, 23(1), 59-64.

Jonsen, A. R. (1998). The birth of bioethics. New York: Oxford University Press.

Molewijk, B., Stiggelbout A.M., Otten W., Dupuis H.M., \& Kevit J. (2004a). Empirical data and moral theory. A plea for integrated empirical ethics. Medicine, Health Care and Philosophy, 7 (1), 55-69.

Molewijk, B. (2004b) Integrated empirical ethics: In search for clarifying identities. Medicine, Health Care and Philosophy, 7 (1), 85-87.

Proceedings of SPT 2009: Converging Technologies, Changing Societies. July 7-10, 2009, University of Twente, Enschede, The Netherlands:

http://www.utwente.nl/ceptes/ceptes_activities/Archive\%20activities/spt2009/programme/proceedings.pdf

Leget, C., Borry, P. \& de Vries, R. (2009). 'Nobody Tosses a Dwarf!' The relation between the Empirical and the Normativity Reexamined. Bioethics 23 (4), 226-235.

Roco, M. C. \& Bainbridge, W. S. (Eds.) (2002). Converging technologies for improving human performance: nanotechnology, biotechnology, information technology and cognitive science. U.S. National Science Foundation: http://www.wtec.org/ConvergingTechnologies/Report/NBIC_report.pdf

Scheer, L. van der, \& Widdershoven, G. (2004a). Integrated empirical ethics: loss of normativity? Medicine, Health Care and Philosophy, 7 (1), 71-79.

Scheer, L. van der, \& Widdershoven, G. (2004b). A response to Levitt and Molewijk. Medicine, Health Care and Philosophy, 7 (1), 89-91.

Stahl, B. C., \& Rogerson, S. (2009). Landscapes of Ethical Issues of Emerging ICT Applications in Europe. In M. Bottis (Ed.), 8th International Conference Computer Ethics: Philosophical Enquiry, (p. 719-737),. Athens: Nomiki Bibliothiki.

Widdershoven, G., Molewijk, B., \& Abma, T. (2009). Empirical Ethics as Dialogical Practice. Bioethics 23 (4), 236-248.

Wodak, R. \& Krzyzanowski, M. (Eds.) (2008). Qualitative Discourse Analysis for the Social Scienecs. Basingstoke: Palgrave.

Wodak, R. \& Meyer, M. (Eds.) (2009). Methods of Critical Discourse Analysis. 2nd Ed. London: Sage.

\section{About the Author}

Pak-Hang Wong

Pak-Hang Wong finished both his BA (1st Hons) in History \& Philosophy and M.Phil in Philosophy at the University of Hong Kong, and has taught Philosophy and Liberal Studies at various tertiary institutions in Hong Kong. He is currently a PhD Research Fellow at the Department of Philosophy, University of Twente. He is currently working on his PhD research project, "Cultural, Political and Religious Ideologies and the Appraisal of New Media", which is a sub-project of the VICI project on the "Evaluation of the Cultural Quality of New Media" funded by Netherlands Organization for Scientific Research (NWO). 